Cumhuriyet International Journal of Education-CIJE

e-ISSN: 2147-1606

Vol 3 (1), 2014, pp. 1-14

\title{
The Effect of Smart Board Centered Micro-Teaching Activities on Science Teachers' Technological Pedagogical Content Knowledge (Tpack) and Their Perceptions towards Using Smart Board
}

\author{
H. İbrahim AKYÜZ1 ${ }^{1}$ Murat PEKTAŞ², M. Altan KURNAZ ${ }^{3}$, Esra KABATAŞ MEMİ̧̧4
}

\section{Summary}

\section{PURPOSE}

Nowadays, using technology effectively for teaching purposes emerges as a competence as it does for daily life. It is noteworthy that teachers believe in the importance of instructional use of technology; but they could not integrate technology effectively in teaching process due to some obstacles. These obstacles include having negative attitude towards the use of technology, misunderstanding the concept of integrating technology into instruction, and not being aware of the technological developments. With the implementation of FATIH Project, Ministry of Education aims to improve the competence of use of technological tools, such as smart boards, through in-service training to the teachers. They also await this competence from teacher candidates when they were graduated. This and similar qualifications are called technological pedagogical qualifications. Literature indicates that teachers who use smart boards in their lessons have better technological pedagogical content knowledge than those who does not. TPAB is regarded as a teacher qualification of our era. One of the tasks of the Faculty of Educations is to graduate teachers with a high level of TPAB. The current study aimed to investigate the effect of smart board centered micro-teaching activities on science teachers' technological pedagogical content knowledge (TPACK) and their perceptions towards using smart board. Being in line with the targeted aim, the research questions were as following:

Before and after the teaching of science teacher candidates is there a significant difference between TPAB scores?

Before and after the teaching of science teacher candidates is there a significant difference between perceptions towards smart board?

\section{METHOD}

\section{Research Design}

Among the experimental design, "One Group Pretest - Posttest Design" was used in the study. Prior to the experiment (pre-test) and post-test (final test) measurements are included in this model (Karasar, 2000; Akgün, Büyüköztürk, Çakmak, Demirel \& Karadeniz, 2012). The reason for not using control group was to reduce the impact of the instructor in the classrooms and ensure that all students are exposed to the same effect.

\section{Sampling}

The study group of consist of 52 teacher candidates who were students at Kastamonu University, Faculty of Education, Department of Elementary Education, Department of Science Education during the academic year of 2012-2013 and who attended Special

\footnotetext{
1 Assist. Prof. Dr., Kastamonu University, Faculty of Education, hakyuz18@hotmail.com

2 Assist. Prof. Dr., Kastamonu University, Faculty of Education, mpektas@kastamonu.ed.tr

${ }^{3}$ Assoc. Prof. Dr., Kastamonu University, Faculty of Education, altan.kurnaz@gmail.com

${ }^{4}$ Assist. Prof. Dr., Kastamonu University, Faculty of Education, ekmemis@kastamonu.edu.tr
} 
Teaching Methods Course. 4 teacher candidates, who did not attend and participate in lessons throughout the experimental period were excluded from the study. Hence, the participants included a total of 48 teacher candidates ( male $=9$, female $=39$ ).

\section{Data Collection Tools}

Two instruments were utilized to collect data. The first one was Technological Pedagogical Content Knowledge (TPACK) Self-confidence Scale. (TPACK) Self-confidence Scale was developed by Graham, Burgoyne, Cantrell, Smith and Harris (2009) and adapted to the Turkish language by Timur and Taşer (2011), was used in the study. Interactive Whiteboard Student's Perception Survey, second instrument, was developed by Türel (2011) and was used to measure teacher candidates' perceptions of smart board.

\section{RESULTS}

The effect of using smart board on science teachers' technological pedagogical content knowledge and perceptions towards the smart board were investigated with this study. This study is limited to 48 science teacher candidates and Private Teaching Methods Course. According to the results, using smart boards as teaching method had a positive effect on TPAB self-confidence of teacher candidates in general and did not change teacher candidates' perceptions towards smart boards. An investigation of teacher candidates' perceptions of smart boards also indicated that the experiment did not change teacher candidates' positive perceptions towards smart board. 